Revue

d'ethnoécologie
Revue d'ethnoécologie

$20 \mid 2021$

Un siècle d'ethno-machins : le centenaire de la Revue de Botanique Appliquée

\title{
Making the most of grasslands and heathlands
}

Unearthing the links between soil paring-and-burning, plaggen

cultivation, and raised-field agriculture

Valoriser les prairies et les landes: exhumer les liens entre écobuage, culture de plaggen et agriculture sur champs surélevés

\section{Doyle McKey}

\section{(2) OpenEdition}

\section{Journals}

Electronic version

URL: https://journals.openedition.org/ethnoecologie/8120

DOI: 10.4000/ethnoecologie.8120

ISSN: 2267-2419

\section{Publisher}

Laboratoire Éco-anthropologie

Electronic reference

Doyle McKey, "Making the most of grasslands and heathlands", Revue d'ethnoécologie [Online], 20 |

2021, Online since 31 December 2021, connection on 06 March 2022. URL: http://

journals.openedition.org/ethnoecologie/8120 ; DOI: https://doi.org/10.4000/ethnoecologie.8120

This text was automatically generated on 6 March 2022

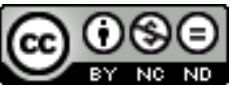

Revue d'ethnoécologie est mis à disposition selon les termes de la licence Creative Commons Attribution - Pas d'Utilisation Commerciale - Pas de Modification 4.0 International. 


\section{Making the most of grasslands and heathlands}

Unearthing the links between soil paring-and-burning, plaggen

cultivation, and raised-field agriculture

Valoriser les prairies et les landes: exhumer les liens entre écobuage, culture de plaggen et agriculture sur champs surélevés

Doyle McKey

\section{Introduction}

\section{The particular problems faced by early farmers of grassland and heathland environments}

1 Of the kinds of environments cultivated by early farmers with simple tools, some bore little vegetation, and preparing land for planting crops was a relatively simple task. Crops could be planted directly on sediments left by receding floodwater in alluvial plains (Mazoyer \& Roudart 1997) ; and in semi-arid habitats, sparse vegetation cover could be removed with relatively little effort (Sigaut 1975) ${ }^{1}$. In other environments, preparing an area for cultivation required more effort. Forest is often seen as the kind of vegetation cover that posed the greatest obstacle to conversion of land for agriculture. However, early farming spread first in forests, and only later to grasslands, which were first used by foraging peoples and pastoralists (Mazoyer \& Roudart 1997). For pre-industrial farmers, agriculture in grasslands poses two main difficulties compared to agriculture in forest.

2 First, depending on the amount of rainfall, herbaceous and low woody vegetation has a more or less dense mat of roots near the surface. Unless this mat is broken up and most plants killed, the crops planted will face severe competition from weeds. Before the arrival of modern plows, preparing the soil for cultivation was hard work indeed. Today, subsistence farmers in many parts of the world consider preparing plots for 
cultivation in grasslands and heathlands to be harder work than preparing fields in forest (FS). For example, « the Banjarese of Borneo report that the annual labor costs of cultivating grassland fields by hoe and plough are about twice that of making swiddens in the forest using axe and fire " (Dove $2004: 433$ ), and the Ogan of Sumatra prefer to open forest for their farms rather than grassland because of the greater work required for the latter (Dove 1986). In contrast, clearing forest for cultivation requires less labor. Under a canopy of large trees, which could be felled by polished stone axes, understory woody vegetation is relatively sparse and easily removed, and herbaceous plants are few. Thus, after the vegetation is slashed, dried, and burned, little soil preparation is required. Crops can be planted in small pockets or holes scraped or dug in the soil. In contrast, before the mould-board plow, cultivating grassland demanded a huge amount of labor to break up the mat of roots and to control weeds. As argued by FS (p. 167) for early farming in Europe, «le plus grand ennemi de l'agriculture autrefois, c'était, non pas l'arbre, mais le gazon. » ("The greatest enemy of agriculture in the past was not the tree, but the grass. ») Similarly, in North America, European colonists cleared farms in forests, but the advance of farming was halted in the prairies, until the arrival of the mould-board plow.

3 Secondly, grasslands and heathlands contain lower above-ground plant biomass per unit area than does forest. The fertility of an environment depends in part on its soil, but also in large part on the plant biomass it holds, and how agricultural techniques transform this biomass (Sébillotte 1993). In plots cleared from forest, the quantity of nutrients released from above-ground plant biomass and litter (usually as ash, after burning) is much larger than if an equivalent area of grassland or heathland were to be burned (Mazoyer \& Roudart 1997). In contrast, the fertility of grasslands depends heavily on below-ground biomass and organic matter. Natural grasslands of the midlatitudes cover some of the world's richest soils, and when the prairies of the American Great Plains and the steppes of Ukraine and Russia were brought under cultivation on a broad scale during the 19th Century, this led to huge increases in food production. However, cultivation of these grasslands was based on nutrients stockpiled in soils over centuries and depleted in a few decades (Güldner et al. 2021). ${ }^{2}$ Soils of tropical savannas (e.g., African savannas: Denevan \& Turner [1974]) have lower amounts of stockpiled nutrients. ${ }^{3}$

4 For these reasons, early farmers in many parts of the world preferred to clear forest for cultivation rather than more open vegetation, and used systems of rotational cultivation to maintain forest land, «abandoning » cultivation of a plot before weeds become a problem. If periods of cultivation are short enough, weeds do not increase much, and if fallow periods are long enough, weed inoculum declines. Furthermore, during a long fallow the nutrient stocks in biomass are restored, and this biomass ensures the fertility of the plot upon renewed cultivation. But if fallow periods are shortened - for example, if demographic pressure leads to scarcity of forested land plots are increasingly invaded by herbaceous plants, principally grasses. The cycle of positive feedbacks between grass and disturbance, principally fire, then leads to replacement of forest by grass-dominated ecosystems (Ruthenberg 1971) - and in the cold, humid climates of northern Europe, by heathlands (Webb 1998).

$5 \quad$ Heathlands in Europe (Webb 1998) and grasslands in many parts of the world (e.g., New Guinea [Denham 2018] and South-East Asia [Dove 1986, 2004]) are anthropogenic, but grasslands of natural origin also cover large areas in the savannas of Africa and South 
America. Whether in natural grasslands or in grasslands and heathlands resulting from their activities, farmers had to solve the two big problems of cultivating these new environments : controlling weeds and (often) dealing with low fertility. Farmers devised new ways to control weeds. Plants that were « weeds » in forest-based systems became positively valued sources of organic matter and nutrients for crops in grassland-based systems (Dove 1986). Farmers also devised new ways to more efficiently use biomass and organic matter, not only that present above-ground, but also that in the soil. They also devised strategies to concentrate nutrients from larger areas onto smaller cultivated areas, either indirectly, by using grazing and browsing livestock as nutrient concentrators (Christiansen 1996), or directly, by carrying topsoil and organic matter from one part of their territory to another.

\section{Grassland agriculture as the Cinderella of indigenous agricultural systems}

6 In two remarkable publications over 45 years ago, Portères (1972) and Sigaut (1975) described and analyzed the techniques used by early farmers of grasslands and heathlands in Europe - and by present-day farmers elsewhere - to prepare the soil for cultivation. Both publications were centered on écobuage. An old word apparently first used in scientific literature by Olivier de Serres in 1600 (FS), this term has been variously employed. Injecting some order in the terminological chaos, these two authors still arrived at slightly different definitions. The key feature of écobuage is the cutting of turves or sods using various tools. RP considered "classical écobuage " to include the slow, incomplete burning of sods after they were cut, which was the most widespread variant of the practice in Europe. FS restricted écobuage to mean the operation of cutting the sods ; burning of sods was one of many variants in operations following sod cutting. Both authors attempted to explain the variation among systems. After a description of «classical » écobuage in Europe, RP reviewed closely analogous cases elsewhere in the world and also described variants unknown in Europe. Portères died two years after publication of his article. Sigaut, with whom Portères had collaborated, published a monograph-length analysis of European systems of écobuage, with references on similar practices elsewhere. While Sigaut's monograph is much more comprehensive, it is hardly available: the book is out of print, no online version exists, and few libraries possess a copy.

$7 \quad$ No publication in English on this subject approaches the breadth and depth of these two syntheses of soil-preparation techniques in grassland agriculture. Finding English terms to describe the various techniques is thus a problem. RP's definition of «classical» écobuage corresponds to "soil paring and burning». In one of the few publications in English that treat the subject (and its terminological problems), Fairhead et al. (2017) focus on present-day examples of this variant. Although more modern, the term «soil paring and burning » is hardly better known to researchers than the term used by 19th-century British agronomists to describe the practice: "denshiring", derived from the frequency of the practice in the heathlands of Devonshire. There are no widely accepted terms to describe the various soil-paring systems. As a result, researchers are often unaware of work by others that they should know. In this paper, I will use "soil-paring systems» to group all the systems that 
share this key trait, and «paring-and-burning » to signify one of the most widespread variants.

8 Today, farming in these environments is so thoroughly associated with the plow, and with artificial fertilizers, that the adaptations of early farmers to cultivating them have been largely forgotten. Although the history of agricultural techniques in Europe has been richly documented, this knowledge, especially as it concerns grasslands and heathlands, is mostly confined to specialists. Even in France, where the pioneering work was done, the term écobuage is today most frequently used erroneously, to refer to the burning of shrubby vegetation, and usually as a pastoral, rather an agricultural, practice. Sigaut's annoyance at the widespread misuse of a term he had tried so hard to clarify and analyze is evident in his last writings (Sigaut \& Morlon 2010). In North America, where there was no history of farming of the great prairies before the plow, the history of grassland farming before the plow is even less known. The publications by RP and FS deserve to be more widely known outside France. They are thus heavily cited here.

Although these early techniques of cultivating grasslands and heathlands have disappeared from Europe, they are still alive elsewhere, and agricultural systems based on these techniques are crucial to the subsistence of many people. But even where these systems are still functioning, their study has been neglected (Dove 2004). Whereas the investigation of indigenous (or «traditional») agricultural techniques in forest environments is burgeoning - witness the flood of studies of rotational agriculture ("slash-and-burn ») in tropical forests done by agronomists, ecologists and anthropologists (e.g., Cairns 2015) - traditional grassland agriculture is the neglected Cinderella.

\section{Goals of this study}

10 The objective of this paper is to update and extend the syntheses of soil-preparation techniques in traditional grassland agriculture begun by RP and FS. First, I examine the functions of soil paring. Why is it practiced? Why, in some systems, is the pared soil then burned? What are the effects of burning the pared soil, on the soil itself and on crops? In what kinds of environments are (and were) soil-paring techniques used? I then examine the diversity of practices encompassed by soil-paring systems. I show that, despite these pioneer papers almost half a century ago, these systems have been studied as separate phenomena or as individual cases by different communities of researchers who seem to be largely unaware not only of the early syntheses but also of each other's work. Faced with this diversity, I attempt to explain the determinants of variation among systems in important traits. Why, after paring and often burning of their sods, are some grasslands and heathlands cultivated in situ, while in other cases the unburned sods are transported for use elsewhere, in massive transfers of fertility from one part of the territory to another? Why in some systems does combustion play the dominant role in the mineralisation of nutrients from organic matter, whereas in others decomposition plays the dominant role? Treating the entire diversity of traditional grassland agricultural systems within a broad comparative perspective is beyond the scope of this paper. I will compare three common, widely divergent variants. Also, given the fragmentary nature of literature on this subject, I will focus on 
framing questions and hypotheses about determinants of variation, rather than offering firm conclusions.

\section{Soil paring and burning}

11 Soil paring and burning is a technique to farm grassland or heathland soils that could not be cultivated by other means. RP and FS showed that this method was widespread in many parts of France and in the British Isles, and in several other countries in Europe, up to the second half of the 19th century. They also documented its practice today in various places in Africa and Asia. Often performed on soils not previously cultivated, it can also be used to restore soils degraded by deforestation, mechanization, or other disturbances. The technique consists of five steps: (i) Using hoes, shovels, or similar tools (even various kinds of simple plows), the soil is pared or "peeled» by removing large, but thin sods, i.e., vegetation with soil clinging to the root mats. (ii) The sods are dried. Sods are usually turned over (grass side down), but never shaken, so that the soil remains attached to the roots. (iii) The dried sods are arranged into loosely packed mounds, up to $1 \mathrm{~m}$ high, to form a veritable oven, often with an opening in the top or side that can be partially blocked, or further opened, to regulate air circulation and thereby the conditions of the burn (Figure 1). (iv) The ovens are ignited and undergo a slow and incomplete burn over several days. (v) The remains of the collapsed ovens - mounds containing ash, burnt soil, and some charcoal - are scattered over the area to be cultivated. Variants of this system exist. For example, in some peaty soils in Europe, the organic matter-rich sods were pared and dried and ignited in situ without mounding (FS ; Menbrivès et al. 2019). In some parts of Africa, pared soil is heaped into ridges for drying and burning, rather than into mounds (RP, Cabot 1965, Grangeret-Owona 1997, Nzila 2017). 
Figure 1 : Paring-and-burning (" classical écobuage ") as it was practiced in Europe up to the early 20th century. Reproduction of Figures 1 and 2 in Portères (1972), showing the different kinds of oven-like structures formed (his Fig. 1). His Fig. 2a shows mounds of sods and vegetation in a field prepared for ignition; Fig. $2 \mathrm{c}$ shows the profile of a mound before combustion, depicting vegetation covered by soil.; and Fig. 2 e shows profiles of mounds after slow combustion.

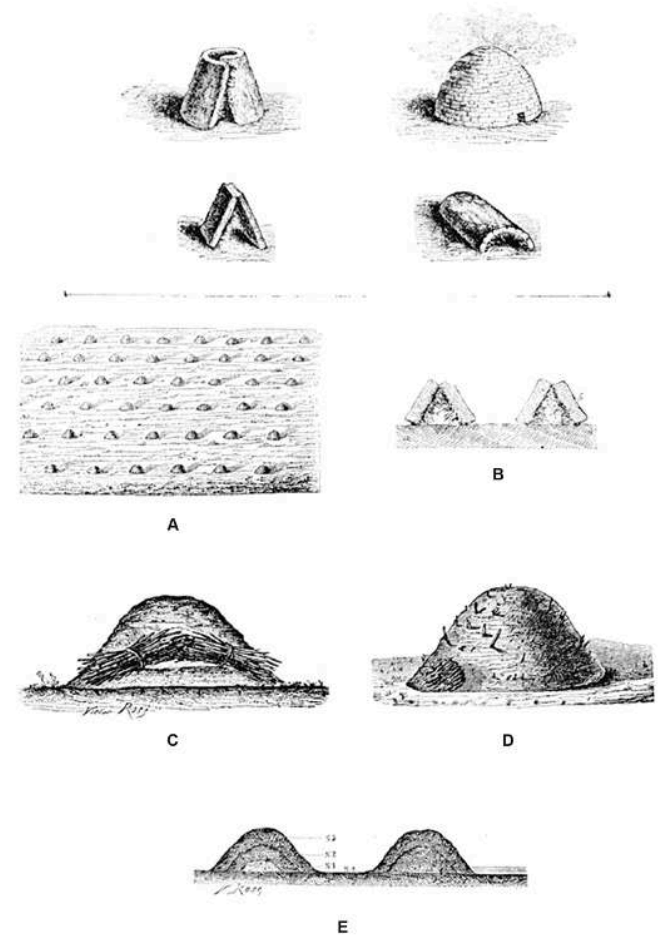

12 Paring-and-burning is practiced on a rotational basis. The duration of periods of cultivation and of fallow varies greatly among cases. In Europe, cycles varied from 3-4 years in cultivation followed by 10-30 years or more in fallow, to 10-12 years in cultivation followed by a fallow of equivalent duration (FS). In grasslands on exhausted soils of the Fouta-Djallon Plateau, Guinea, rotations were on the order of one year cultivation followed by nine years fallow (or sometimes much longer, up to 50 years), whereas in the Logone floodplains of Chad, plots cultivated for a single year are then left in fallow at least four years (RP). In montane grasslands of the Ethiopian highlands, annual crops were customarily grown on pared-and-burned plots for two or three consecutive years and then left fallow for seven to more than 15 years (Pülschen \& Koch 1990).

\section{Effects of soil paring and burning}

13 FS documented numerous positive effects of paring-and-burning on the quality of soil for crop production. First, heating the soil kills many weed seeds, insect pests, and soil pathogens: «Fire was the first pesticide » (FS : 100). Secondly, fire mineralizes organic matter, lowering the $\mathrm{pH}$ and mobilizing nutrients for uptake by crops. In contrast to forest-clearing techniques, not only the above-ground biomass, but also the soil and its below-ground biomass and organic matter are combusted. Soil burning is thus a way to use more efficiently the limited biomass available in non-forest vegetation. The importance of paring and burning the soil, rather than just reducing vegetation to ashes, is highlighted by the fact that farmers preferred to pare and burn soil in these 
sites, despite the fact that it requires much more labor. Soil burning is most effective in waterlogged soils where organic matter is abundant and where acidity, cold, and high concentrations of tannins and other recalcitrant compounds strongly limit decomposition rates. Not all of the humus is destroyed by soil burning, but heated humus has a faster rate of mineralisation, releasing nitrogen that would otherwise have been unavailable (FS). Third, soil burning improves the texture of thick clay soils, causing clay particles to fuse into larger aggregates. The formation of these "pseudosands" dramatically improves drainage conditions. Finally, there is some evidence that calcination of clay results in the release of potassium from the cristalline structure of silicate clays.

All these effects of soil paring and burning noted by FS have been further documented in subsequent studies. Olarieta et al. (2011) conducted an experimental study of the effects of soil paring and burning in the Mediterranean region of Spain, where the sod ovens, made in some sites up until the 1960's, were known as "formiguers». These authors demonstrated all of the positive effects noted by FS. They found that despite the decreased cation exchange capacity associated with combustion of humus and reduction of the clay fraction, availability of bases such as $\mathrm{Mg}$ and $\mathrm{K}$ nonetheless increased. The soil covering the burn also greatly reduced convectional loss of nutrients. Substantial amounts of nitrogen were lost by volatilization, but the availability of phosphorus increased dramatically, by mechanisms as yet unelucidated. In a striking illustration of the fragmented nature of research on soil paring and burning, these authors were apparently unaware of the similar conclusions reached a half-century earlier on very similar soil-preparation methods in grasslands and heathlands one country further north. In the Ethiopian highlands, soil paring and burning is practiced in frequently waterlogged heavy clay soils under humid conditions at 2000-3000 m a.s.l. (Pülschen \& Koch 1990, Amare et al. 2013, Mertens et al. 2015). Again, all the advantages noted by FS were also documented by these authors, who, like Olarieta et al. (2011), were apparently also unaware of the studies done almost fifty years earlier. Only France-based authors writing on soil paring and burning (e.g., Duval et al. [2007], in the Bolivian Andes; Moreau et al. [1998] and Nzila [2017] in the Congo Republic) systematically cite RP, FS, or both, as sources.

In the one publication in English I have found that cites RP, Fairhead et al. (2017) note that the effects of soil burning documented by the above-cited studies are all shortterm. After some period of cultivation, fertility declines, and even the "pseudosand " aggregates eventually disperse, so that soils once again become clay-rich. Fertility must be restored during a period of fallow, followed by renewed paring and burning. Inspired by their experience with charcoal-rich anthrosols such as Amazonian Dark Earths, in which black carbon (charcoal) durably improves fertility (e.g., Glaser et al. [2001]), Fairhead et al. (2017) asked whether the black carbon generated by the slow and incomplete burning of soil could similarly result in long-term improved fertility. A few years earlier, Olarieta et al. (2011) had independently (and unremarked by Fairhead et al. [2017]) asked the same question. Their experimental study of simulated formiguers found that little charcoal appeared to be generated during soil burning. Macromorphological descriptions of soils in the region they studied also reveal little charcoal. However, they acknowledged that macromorphology does not allow identifcation of smaller charcoal particles. In a study comparing potential geoarchaeological markers of different kinds of anthropogenic fire, Guiblais-Starck et 
al. (2020) characterized production of charcoals by soil burning as null to moderate, depending on the kind of combustible material used. They based this conclusion on the density of supra-millimetric particles of charcoal. However, until chemical determination of black carbon has been conducted in soils subjected to paring-andburning, its role in these soils remains an open question.

\section{Soil-paring systems and concentrational agriculture}

16 As mentioned in the introduction, farmers responded to the fertility constraints imposed by grassland and heathland soils in two ways: by making more efficient use of organic matter and biomass present in situ, or by transferring biomass, organic matter and soil from relatively large areas within the territory to create smaller areas of high fertility. Soil paring-and-burning, as described above, acts mainly by the first way. However, soil paring-and-burning also includes elements of concentrational agriculture, albeit usually at small spatial scales. The soil-burning ovens are made by accumulating turves from the surrounding area, in effect concentrating nutrients locally. After the soil-burning ovens are flattened and their ashes and burnt soil are spread, crops still grow better on the spots where the ovens were located, in both Europe (FS) and West Africa (rice in Guinea: RP, p. 179), indicating that fertility was still concentrated in these microsites. Sometimes the ovens are not even broken down after burning (Moreau et al. 1998, RP : 189). Farmers sometimes consciously exploit soil heterogeneity in these systems by planting more demanding crops on the oven sites, or their remains, and less demanding crops in between (Mboukou-Kimbatsa 1997). In all these cases, the degree to which nutrients are locally concentrated appears never to have been quantified. For cases in which the oven sites are not broken up, a rough indication is given by the relative proportions of the surface occupied by mounds or ridges and of interspaces. In the Niari valley, Congo, ridges appear to occupy about onethird of the total surface (see Fig. 3a in Nzila [2017]). Photographs in RP indicate proportions as low as one-fifth in some sites. Ridges and mounds are spaced more widely apart if vegetation is not very dense (e.g., in the Niari valley [Moreau et al. 1998]).

17 In other cases, nutrients are concentrated at a somewhat larger scale. In the «formiguers » system in Catalonia in Mediterranean northeastern Spain (Olarieta et al. 2011), soil-burning ovens in grassland received additional biomass - small branches, leaves, and litter - from considerable areas of surrounding forests (estimated at 10-25 ha per ha of agricultural land) before being covered with soil and burned. Here again, the degree to which farmers decide to concentrate nutrients appears to vary with the fertility of the environment. In western Spain, «formiguer» ovens are constructed from turves without addition of biomass from outside. Under the wetter climate of Atlantic western Spain, soils have higher organic-matter content than soils under the drier Mediterranean climate of eastern Spain, lessening the need for such nutrient addition (Olarieta et al. 2011).

Soil-paring-and-burning plots may also be part of concentrational-agriculture systems at very large spatial scales. Soil paring and burning was used in Europe not only to prepare plots for cultivation, but also to improve the quality of grasslands and heathlands as sources of forage for domestic herbivores (FS, Guiblais-Starck et al. 2020). Such plots thus formed part of the « outfields » in infield/outfield systems, whereby the 
excrement of livestock that foraged extensively in the outfields was concentrated near dwellings and other central locations where livestock congregated at night. Fertility was thus transferred to the infields, where the most demanding crops were grown (Christiansen 1978, 1996).

\section{Plaggen agriculture: Concentrational agriculture on a massive scale by the transfer of cut sods}

19 In addition to paring-and-burning, described above, another soil-paring system was widespread in areas of poor, low-lying sandy soil in northern Europe, where in Medieval times the forests that originally occupied these regions became increasingly degraded and finally replaced by heathlands (Webb 1998). This system, termed "écobuage-étrèpage " by RP and FS and today widely known as "plaggen cultivation " (from German Plaggen, meaning sod), functioned entirely differently from paring-andburning. The pared sods were not formed into ovens, burned, and scattered. Instead, they were transported, unburned and intact, to stables to provide litter for livestock (Figure 2). Mixed with nutrient- and water-rich animal excrement, and placed in the warmer environments of stables and barns, the tough heathland vegetation and organic matter decomposed more rapidly, yielding a rich compost of mineral soil, plant organic matter and animal excrement, which was then applied to arable fields near the stables and dwellings (Figure 3). This practice was conducted over vast areas from Scandinavia and the Netherlands and Belgium east to northern Germany (Blume \& Leinweber 2004) and even Russia (Hubbe et al. 2007). Conducted continuously over a period of 900 years or more in some areas, this process led to the formation of plaggen soils, anthrosols whose profiles include up to $130 \mathrm{~cm}$ of humus-rich topsoil (Figure 4). The region's agriculture was transformed. Before plaggen (and before forest had been converted to heathland), rotational agriculture ("slash-and-burn») in forest is estimated to have allowed a single crop of barley after nine years of fallow (Giani et al. 2014). In contrast, plaggen soils yielded large crops of barley year after year. Plaggen agriculture also transformed the region's landscapes. It is estimated that up to 40 ha of heathland were required to produce and maintain one ha of plaggen soil (Blume \& Leinweber 2004). Plaggen agriculture created heterogeneity in topography and soils throughout the region, with increasingly impoverished soils in basins and increasingly rich soil on higher ground ${ }^{4}$. As the plaggen soils became more and more valuable, there was increasing pressure to use them as intensively as possible. Plaggen agriculture developed into an extreme example of concentrational agriculture and infield-outfield systems (FS). 
Figure 2 : Transport of sods from heathland, Senne region of North Rhine-Westphalia, Germany, ca. 1938. This area of sandy soil has the largest contiguous heath landscape in North RhineWestphalia

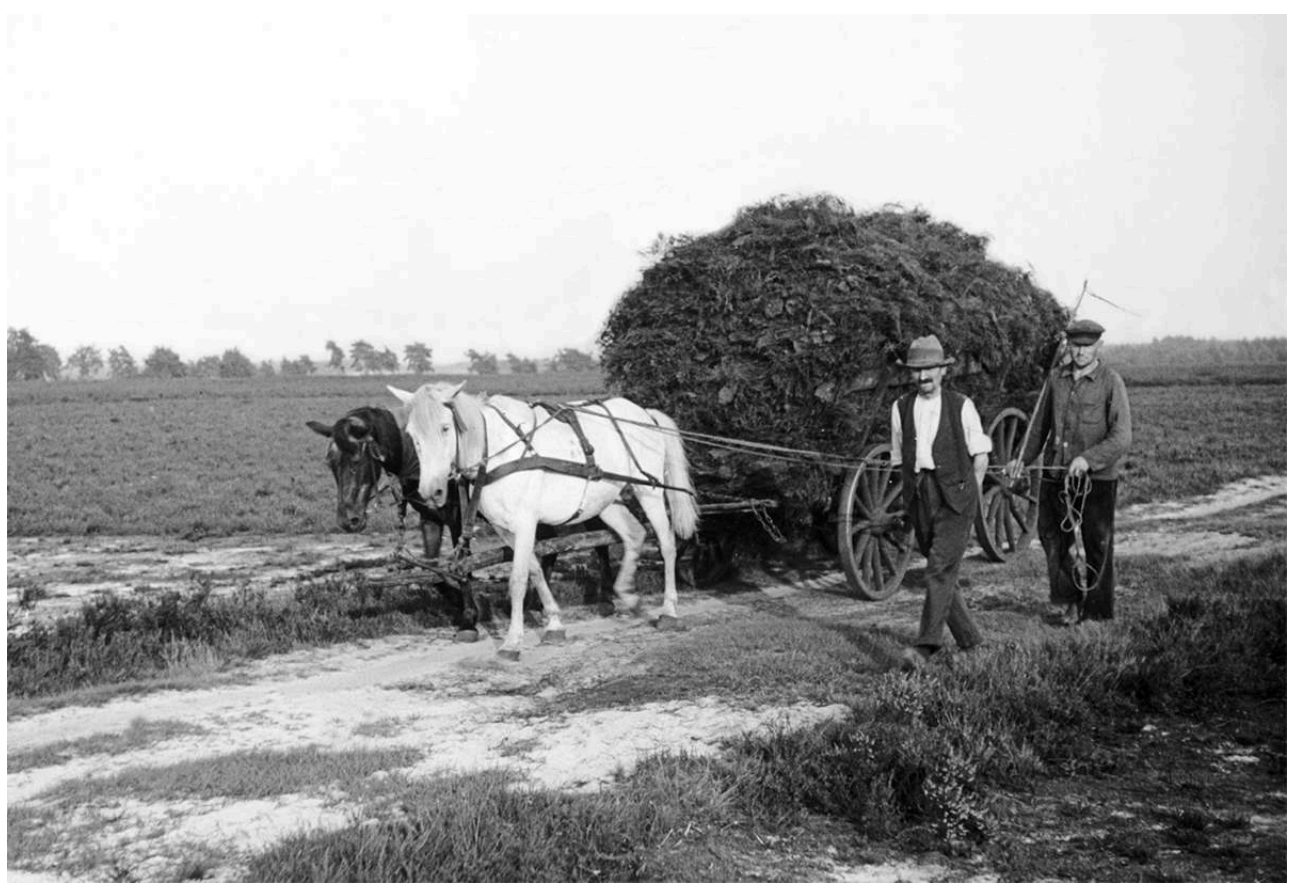

Unknown photographer @ LWL-Medienzentrum für Westfalen, used by permission

Figure 3 : Plaggen agriculture summarized. Sods are cut from heathland and transported to stables, where they are used as litter for domestic animals. Composted plaggen (enriched with animal excrements) is later deposited on arable fields. Drawing by Klaus Thierer (Hochschule Osnabrück, Germany)

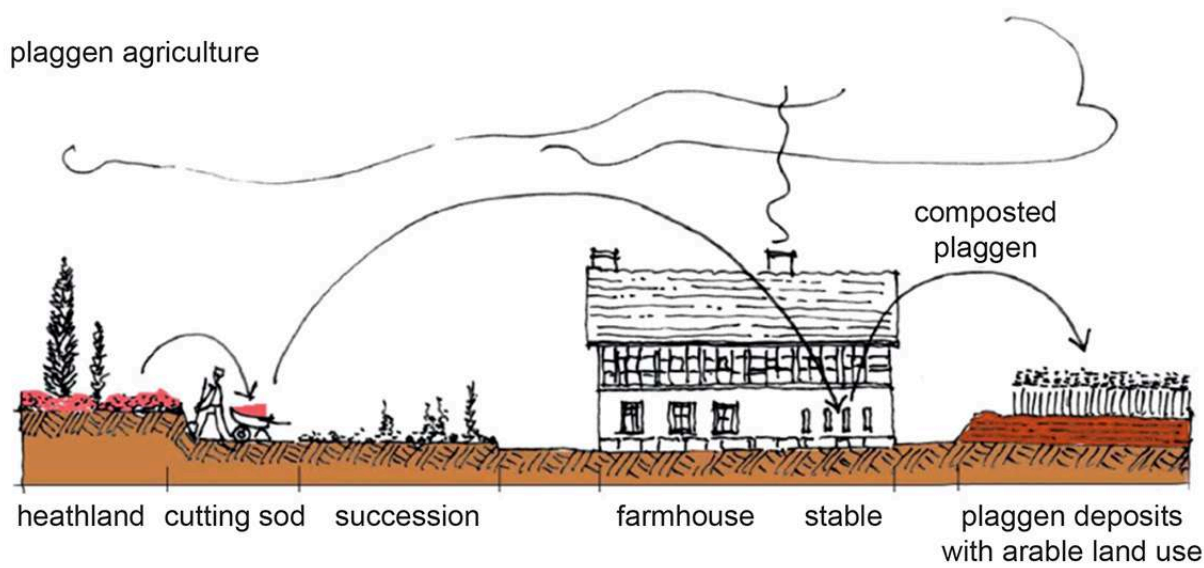

(c) John Wiley \& Sons, 2014. Used with permission of John Wiley \& Sons, from « Plaggic anthrosol: Soil of the Year 2013 in Germany: An overview on its formation, distribution, classification, soil function and threats », (L Giani et al., Journal of Plant Nutrition and Soil Science 177 (3), 2014); permission conveyed through Copyright Clearance Center, Inc. 
Figure 4 : Profle of a grey Plaggic Anthrosol, near Lingen (Emsland, Lower Saxony, Germany). The plaggic horizon is approximately $60 \mathrm{~cm}$ thick. Photo courtesy of Lutz Makowsky (University of Applied Sciences Osnabrueck, Osnabrueck, Germany)

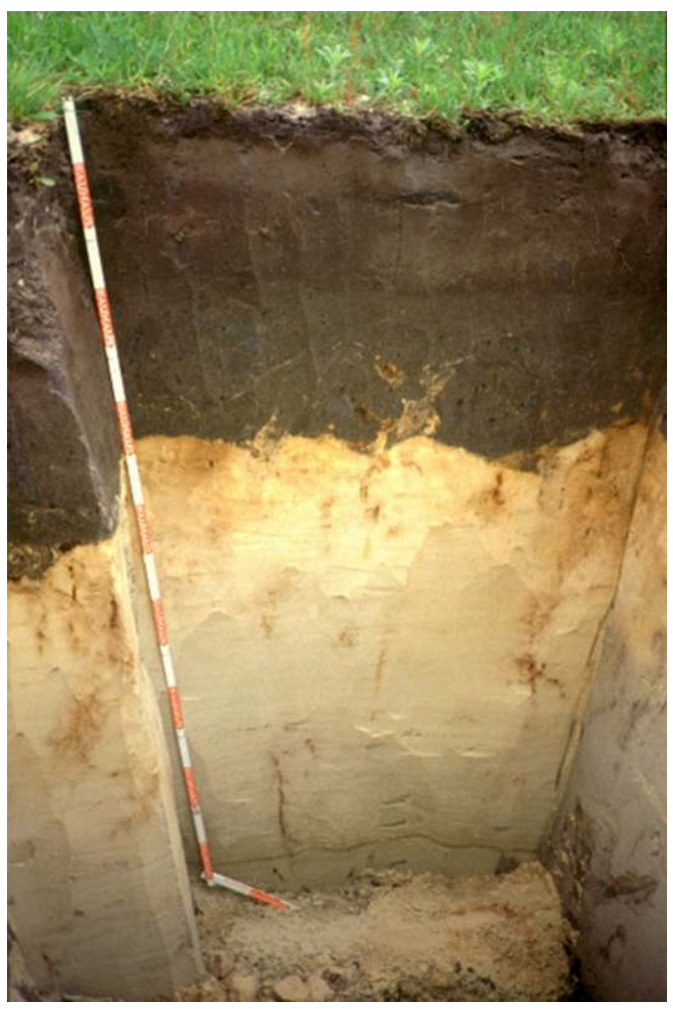

The two most widespread soil-paring farming systems in Europe thus functioned entirely differently, both ecologically and in their social dynamics (FS). In paring-andburning, with the exception of nutrients removed in harvest or by livestock, nutrients were left in situ. Plots were subjected to paring-and-burning on a rotational basis, and fallow periods allowed reconstitution of nutrient stocks. Pared-and-burned heathlands in the landscape were thus relatively homogeneous. Plaggen agriculture, in contrast, created heterogeneous environments. Although plots from which sods were removed were left in fallow, these periods became shorter as cultivation of plaggen soil plots intensified, so that heterogeneity, and further impoverishment of the poorest soils, increased over time. ${ }^{5}$ Plaggen agriculture also required greater mobility, as roads, carts and draft animals were required for the transport of massive quantities of sods (Figure 2).

21 What drove the development of these two systems, both based on soil paring, along such dramatically different trajectories? The geographic distributions of the two systems may offer some clues. Paring-and-burning was widespread in the British Isles, in France and neighboring European countries (FS) and is known from Spain (Olarieta et al. 2011). It is also practiced today in many locations in Africa (RP ; Cameroon: Cabot 1965, Grangeret-Owona 1997 ; Congo: Moreau et al. 1998, Nzila 2017 ; Ethiopia: Pülschen \& Koch 1990 ; SE Africa: Itani 2002) and in Andean heathlands in South America (Duval et al. 2007). In contrast, plaggen agriculture is known only from northern Europe ${ }^{6}$ (the « Maori plaggen soils » described by McFadgen [1980] were produced by very different practices, the transport of sand, and not of turves). In northern Europe, plaggen agriculture was practiced on sandy soils, its distribution closely following the geographic delimitation of Pleistocene coversand deposits (Pape 1970, FS). 
Interestingly, paring-and-burning was almost unknown in sandy regions (e.g., in the Landes of Gascogne in southwestern France, where paring-and-burning was otherwise widespread in clayey soils) and 19th-century agronomists advised against its practice in sandy soils (FS). As FS pointed out, nutrients released by burning would be rapidly leached out of sandy soils, and can be lost permanently if a vegetation cover is not quickly re-established. Paring-and-burning was practiced mostly on heavy clay soils, and it is also on such soils that the practice has the greatest positive effects on soil physical properties.

However, how these systems developed in different ways may also have sociocultural causes. Thurston (2009) posits that the origin of manuring practices in northern Europe was driven not by the needs of agriculture, but by the needs of the primarily pastoral people who inhabited the region before plaggen agriculture began. The heathlands that resulted from forest degradation supported a largely livestock economy, with scattered dwellings associated with small farms (Uhlig 1961). And in the colder climates of northern Europe, the winter stabling of livestock greatly increased the need for litter to be transported to stables to absorb animal excrement (FS). This automatically resulted in the production of larger quantities of compost that could be applied to arable fields, which grew in both area and in fertility. Thus, the reciprocal positive feedbacks between the ecological effects of plaggen agriculture (increasing concentration of fertility) and the social dynamics that gave rise to it (abundance of livestock and their stabling near houses, wide dispersion of these houses) and that resulted from it (intensification of agriculture, need for roads, transport, and animal traction) make it difficult to separate cause and effect in explaining the development of plaggen agriculture. $^{7}$

\section{Another tale of two trajectories: the rise of plaggen agriculture and the fall of paring-and-burning as subjects of research}

Although paring-and-burning was arguably more widespread than plaggen agriculture in Europe - and certainly more widespread in the rest of the world, even today research on paring-and-burning is stagnant, whereas studies of plaggen agriculture are experiencing a minor boom. The neglect of paring-and-burning can be explained, I think, by two facts. First, the seminal publications on this theme are in French, and are rarely read by English-speakers. Secondly, paring-and-burning has not left behind conspicuous legacies like plaggen and other dark-earth anthrosols. Practiced in rotation, it resulted in homogeneous soils not dramatically poorer (or richer) in nutrients than before cultivation. And if paring-and-burning produced accumulations of black carbon, as suggested by Fairhead et al. (2017), this has yet to be demonstrated (Olarieta et al. 2011) and accumulation is in any case likely to be much lower than in terra preta-type anthrosols. In contrast, plaggen agriculture left behind the famous and distinctive plaggen soils (Giani et al. 2014, Urbanski et al. 2022). The presence of these distinctive legacies has stimulated and facilitated research on the history and dynamics of the societies that produced them and live in landscapes shaped by them (e.g., Thurston 2009). 


\section{To burn or not to burn: comparative ecology of soil- paring systems in Africa}

RP described several African examples of classical paring-and-burning systems similar to those known from Europe: on the Fouta-Djallon Plateau in Guinea, in the plateaux occupied by the Bamileke in Cameroon, in the Logone floodplains of Chad, in the Uele province of NE RDC, in the Niari valley (Congo Republic), and in Rwanda and Burundi. Since then, other examples have been documented in Ethiopia (Pülschen \& Koch 1990), Madagascar (Michellon et al. 2001) and SE Africa (Itani 2002) and paring and burning in the Niari valley has been studied in greater depth (Moreau et al. 1998, Nzila 2017) (Figure 5). But Africa also offers examples of variants not known from Europe. RP distinguished "écobuage compostier", in which turves are cut, turned over with the grass side down, and amassed into mounds or ridges, just as in classical paring-andburning systems. But instead of serving as soil-burning ovens, these structures are compost mounds. Vegetation and soil organic matter are mineralized not by combustion, but by decomposition (Figure 6). Fire is not entirely absent from these systems, as tall grass is sometimes burned beforehand to reduce cover and facilitate soil preparation, but care is taken to avoid wildfires and to preserve most of the plant biomass for use as compost (Miracle 1967, Siame 2006). The cases cited by RP were all from East Africa, and several such systems in that region have been studied subsequently (Stromgaard 1988, Stromgaard 1989, Stromgaard 1990, Itani 2002, Siame 2006). All of these cases correspond to variants of systems that are widespread in southeastern Africa, where they are termed fundikila in Zambia and ntumba in Tanzania (Siame 2006). However, studies since 1972 have shown that similar systems are much more widespread than previously documented, being described (albeit usually with few details) from central Africa (Miracle 1967, Fresco 1986, Delêtre 2004, Walters 2012, Rodrigues et al. 2020) and West Africa (Krings 1991). Finding and identifying these systems from the literature is not straightforward, as specific terms such as "soil paring" or "écobuage» are not used. The systems are usually called simply «mound cultivation " or "ridge cultivation». It is not always clear whether the mounds or ridges thus designated are simply masses of piled-up soil or, on the contrary, true composting structures in which large amounts of biomass are covered with soil. Just as in paring-and-burning systems, in some cases the mounds or ridges are scattered and spread out after a certain period of composting, whereas in other cases these structures are not broken up, but instead are planted with crops. In yet other cases, a year of cultivation on mounds alternates with a year of cultivation on scattered composted material. As in paring-and-burning systems, farmers consciously use the heterogeneity in these systems - between mounds and intermound spaces in the same year, between years with mounds and years without, between years in the sequence of cropping from the newly opened plot to the last crop before fallow - to match environments to the needs of different crops (e.g., Stromgaard 1990). As in paring-and-burning systems, mounds and ridges concentrate nutrients on a fraction of the total surface exploited. Where proportions have been noted, topsoil and biomass are concentrated on ridges that occupy $35-40 \%$ of the surface (Nicolai $1963: 249$ ) or on mounds that occupy about one-fourth of the surface (Comptour et al. 2018). As in paring-and-burning systems, cultivation is rotational. In northern Zambia, for example, plots are cultivated for 3-5 
consecutive years, followed by fallow periods reported to range from 5-16 years (Grogan et al. 2013).

Figure 5 : Classical écobuage (soil paring and burning): The maala system, conducted in the Niari Valley, Congo. Top left panel: Preparation of ridges, with dried vegetation (mostly Hyparrhenia diplandra, Poaceae) partially covered with topsoil pared from the surfaces between ridges. Top right panel: Ridges ready to be ignited. Ridges occupy about one-third of the total surface exploited. Bottom panel: Cross-section of a ridge after burning, showing partially charred vegetation and burnt soil (compare with Fig. 2e in Portères (1972), reproduced in Fig. 1 here)

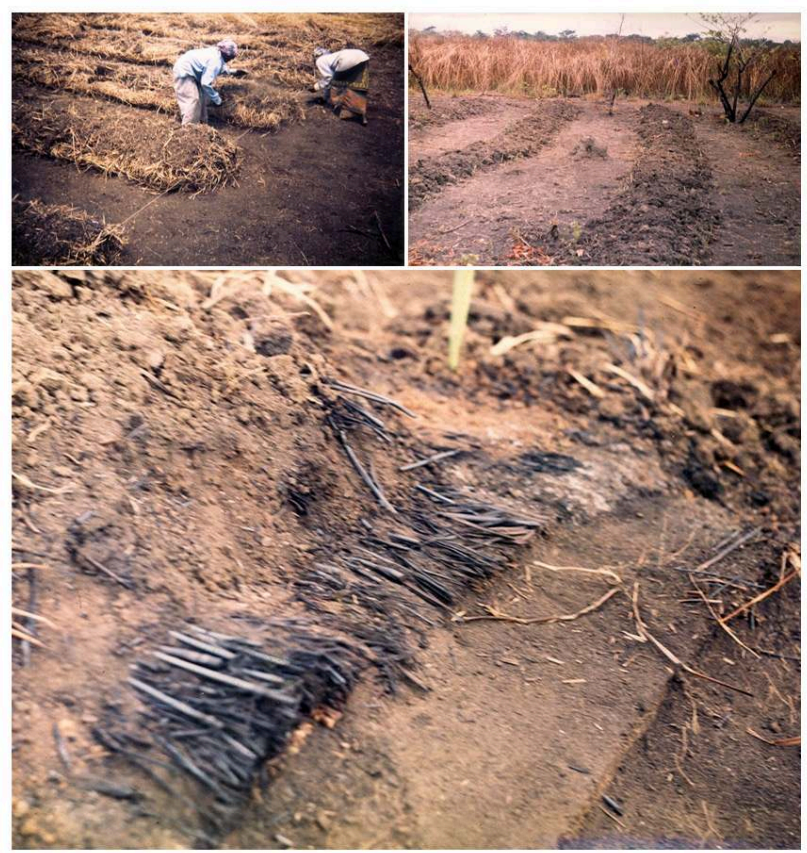

Photos by Prof. Jean de Dieu Nzila (Ecole Normale Supérieure, Université Marien Ngouabi, Brazzaville), used by permission

Why is the accumulated organic matter mineralized by burning in some of these systems, whereas in other cases it is mineralized by decomposition? Itani (2002), in a little-known article published in Japanese, offered a hypothesis to account for this variation. Writing of both forest and grassland farming systems, he distinguished between combustion-based systems and decomposition-based systems for mineralizing organic matter. He proposed that when the cleared vegetation is mostly woody, farmers will use fire to mineralize nutrients in organic matter, because woody vegetation decomposes too slowly to provide nutrients for crop growth ${ }^{8}$. In contrast, herbaceous vegetation decomposes rapidly, if conditions in the soil are favorable. Itani postulated that when the cleared vegetation is mostly herbaceous, farmers will usually suppress fire (or minimize its use), conserving organic matter so that nutrients are mineralized and made available to plants by decomposition. This has the advantage that fewer nutrients are lost through volatilization (nitrogen) and ash convection than if the vegetation were burned.

Finally, Itani postulated that farmers will use combustion, not decomposition, to mineralize nutrients of herbaceous vegetation when cold soil temperatures or waterlogged soil limit decomposition rate. (Aridity, not mentioned by Itani, is another 
factor limiting decomposition rate that could favor combustion over decomposition.) Itani found that in East Africa, paring-and-burning is practiced in high-elevation grasslands with cold soils and in waterlogged soils, whereas paring-without-burning is practiced in grasslands with warmer soils and in well-drained soils. Other examples, cited by RP, are consistent with this hypothesis. In Guinea, paring-and-burning is practiced in soils on the Fouta-Djallon Plateau that are waterlogged through the rainy season. Soil is pared, dried, and burned two months before the onset of the rains, so that minerals are available for crop growth rather than trapped in organic matter in the waterlogged soil. Similarly, paring-and-burning is practiced in seasonally flooded soils of the Logone floodplains in Cameroon and Chad (Cabot 1965). Paring-and-burning is also practiced in high-elevation grasslands of the Ethiopian highlands (Pülschen \& Koch 1990, Mertens et al. 2015) and in Rwanda and Burundi (RP). Paring-withoutburning is conducted in grasslands of the miombo ecoregion in SE Africa (Stromgaard 1988, Stromgaard 1989, Stromgaard 1990, Siame 2006) and is widespread in lowland savannas of the western and central Congo Basin (Fresco 1986, Walters 2012, Rodrigues et al. 2020).

Itani's hypothesis also explains the dominance of combustion-based systems in Europe (outside the plaggen system, of course) and its occurrence in the Andes. In both regions, paring-and-burning is (or was) usually practiced in cold, acid, and often waterlogged soil. The tannin-rich, difficult-to-decompose vegetation of heathlands also favored the choice of combustion-based systems.

Itani's hypotheses thus appear capable of explaining patterns of variation in whether farmers use combustion or decomposition to mineralize nutrients. However, they do have one important limitation: soil-paring farmers not only adapt to the constraints that environments place on them, they can also modify environments in ways that partially lift these constraints. For example, farmers cultivating waterlogged areas can, if they construct mounds large enough, create islands of well-drained soil in which organic matter decomposes rapidly. Also, if compost mounds are large enough, rotting vegetation in them can substantially raise the temperature of the soil. Through this effect on microclimate in the soil (along with higher air temperatures above mounds compared to inter-mounds during night-time temperature inversions [Waddell 1975]), cultivation of large compost mounds allowed the extension of sweet potato into areas of the New Guinea highlands prone to radiation frost (Denham 2018). The greater the frost risk, the more compost farmers add to the mounds (Taraken \& Ratsch 2009). Thus, to a certain extent the construction of compost mounds, if they are built large enough, can help to solve the very problems that Itani thought would exclude them from certain environments.

Soil type is another factor that may influence the distribution of combustion-based vs. decomposition-based systems. As developed above, in Europe paring-and-burning was practiced on heavy clay soils and never on sandy soils. The same may be true in Africa. Paring-and-burning systems in Ethiopia and Senegal are practiced on heavy clay soils. In savannas of the western Congo Basin, the "Maala » paring-and-burning system is practiced only on ferrous, clay soils in the Niari Valley and in some parts of the Bateke Plateaux (Mboukou-Kimbatsa 1997, Moreau et al. 1998, Nzila 2017). In contrast, in sandy soils of this region, paring-without-burning (compost mounds or ridges) is practiced (Fresco 1986, Walters 2012, Delêtre 2004). However, compost-mounding is not restricted to sandy soils. The large compost mounds (raised fields) in savanna 
floodplains near Mossaka, in the central Congo Basin, are constructed in clay soils (Rodrigues et al. 2020). In the New Guinea highlands, sweetpotato is grown on compost mounds in soils ranging from sandy loam to heavy clays (Taraken \& Ratsch 2009).

\section{Bringing raised-field agriculture into the fold of soil- paring systems}

Raised-field agriculture has long been studied as a unique system adapted to wetlands. Although the pioneering review by Denevan \& Turner (1974) showed that African raised fields are also found in well-drained grasslands, improving drainage has usually been viewed as a principal function of raised fields (Rodrigues et al. 2020). The study of raised-field agriculture has been dominated by work on archaeological systems in South America and Mesoamerica. No one appears to have ever connected raised-field agriculture to soil-paring systems. Our recent studies of present-day raised-field agriculture in Africa show that in both Zambia (McKey et al. 2017) and the Congo Republic (Rodrigues et al. 2020), raised fields are made by cutting turves and concentrating large quantities of vegetation, with their associated root mats, along with topsoil from the surrounding area, to make large compost mounds. « Raised-field agriculture » thus fits within the concept of «écobuage compostier» (Figure 6). (Mound or ridge cultivation is also conducted on pared-and-burned soils, e.g., in the Niari Valley [Nzila 2017]). Furthermore, raised fields are constructed in both wetland-margin and upland environments, the only difference between them being the larger size of fields in flood-prone environments (McKey et al. 2017). All these facts suggest that the most general function of raised fields is to serve as compost mounds, with those in wetlands and wetland margins acquiring the additional function of avoiding flood risk. Similar conclusions apply to raised-field agriculture («mound cultivation») in New Guinea (Taraken \& Ratsch 2009). Whether pre-Columbian raised fields in the Neotropics were built and cultivated in the same way is a question that awaits new geoarchaeological studies.

Figure 6 : Construction of agricultural raised fields in a seasonally flooded savanna near Mossaka, Republic of Congo. Sods and topsoil are cut from an area surrounding the new field and fashioned into a large circular mound. The newly constructed field in the panel on the right, about $8 \mathrm{~m}$ in diameter, has just been planted with stem cuttings of manioc

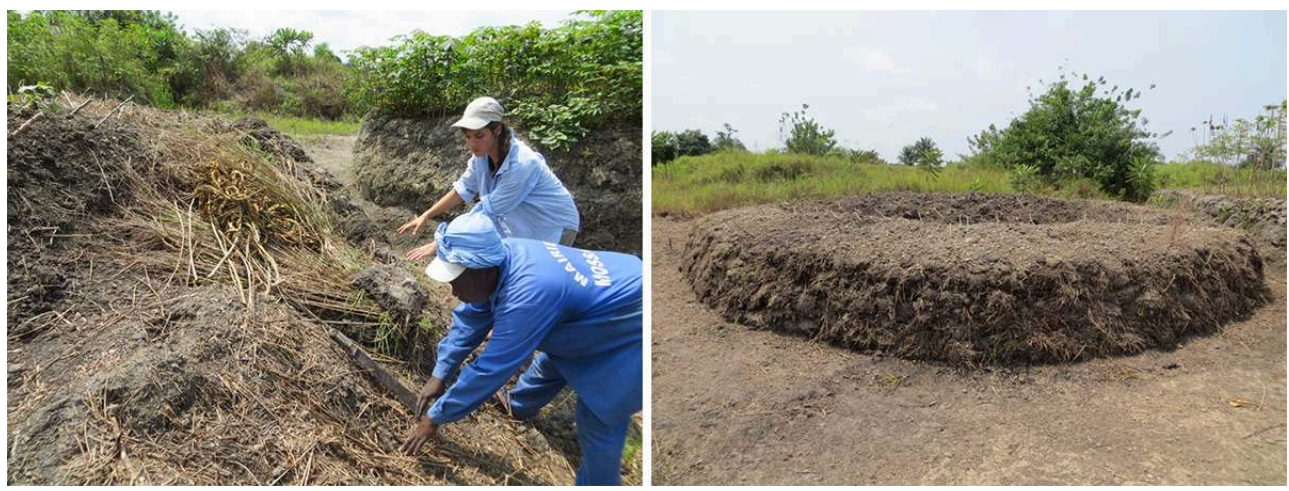

Photos by Dr. Leonor Rodrigues (Agroscope, Switzerland), used by permission. 


\section{Perspectives}

31 Almost nothing is known about several important aspects of soil-paring systems. For example, aside from works that show the initial negative effects of soil burning on weeds and insect pests (FS, Pülschen \& Koch 1990), I know of only one study - an unpublished PhD dissertation (Mboukou-Kimbatsa 1997) - that examines the effects of cultivation under paring-and-burning on soil organisms, and that study treats only macro-invertebrates. In the Niari Valley, Congo Republic, earthworms, termites, and ants are abundant in pared-and-burned soils for up to three years after paring and burning, whereas plots that were subjected to running fires had much lower densities (Mboukou-Kimbatsa 1997). For paring-without-burning (compost-mound) systems, Rodrigues et al. (2020) showed the importance of soil mesofauna in decomposition processes within mounds. Physical and chemical properties of plaggen soils have been extensively studied (e.g., Blume \& Leinweber 2004, Urbanski et al. 2022), but surprisingly little appears to be known about organisms living in them.

With the notable exception of plaggen agriculture, little is known about the history (and pre-history) of soil-paring systems. The first descriptions of paring-and-burning by agronomists in Europe date back only to the 18th century, and FS considered that in Europe the practice may have begun as late as the 16th Century, and certainly not before the widespread availability of iron tools. However, these conclusions can be challenged. FS himself noted that variants of soil paring are practiced (or were practiced historically) with wooden shovels in New Guinea, and in the Andes with the famous chaquitaccla foot-plow. Furthermore, Guiblais-Starck et al. (2020) believe that paring-and-burning was practiced in Europe long before it was historically documented, as early as the end of the Early Middle Ages. They pointed out that paringand-burning has been systematically ignored in archaeologists' interpretations of how humans used fire in agriculture. In a pioneering methodological study, they proposed geoarchaeological criteria for distinguishing paring-and-burning from other alternative interpretations of vestiges, such as clearing and burning of forest vegetation, or running fires in grassland. They provided evidence that paring-andburning was practiced in a site near Vaudes (north-central France) in the 11th-12th centuries. As these authors (and Menbrivès et al. [2019]) point out, paring-and-burning should leave behind distinctive traces, but unlike the conspicuous plaggic horizons of plaggen soils, detecting these traces requires meticulous analysis of micro-charcoal and microfossils. These studies offer hope for geoarchaeological investigations of paringand-burning for those willing to confront the technical challenges. The challenges geoarchaeologists face in finding vestiges of paring-without-burning (compost-mound cultivation) may be even greater (Rodrigues et al. 2020).

The future of soil-paring systems is as murky as their past. Do they have any role to play in the agro-ecological transformation of agriculture? As related by FS, there was already lively debate in 19th-century Europe about whether the practice of paring-andburning degrades soils, and this debate continues in areas where paring-and-burning persists today (Pülschen \& Koch 1990, Fairhead et al. 2017). FS considered paring-andburning to be ecologically sustainable, given long enough fallow periods, and studies in Ethiopia (Amare et al. 2013) and the Congo Republic (Moreau et al. 1998) support this conclusion. In the latter region, paring-and-burning performs better than any other methods accessible to smallholder farmers (Moreau et al. 1998). This example shows 
that rejecting paring-and-burning as an «archaic» system might be misguided. Similarly, paring-without-burning (compost-mound cultivation) appears to be sustainable in Zambia (Stromgaard 1990) - again, given long enough fallow periods and in the Congo Republic this technique produces yields of manioc that compare favorably with average yields for sub-Saharan Africa (Comptour et al. 2018).

Finally, analysis of soil-paring systems may provide a unique perspective into "notillage agriculture ", also known as "conservation agriculture ». By leaving the soil intact, no-tillage agriculture confers advantages relative to plowing, such as favoring soil carbon storage and reducing erosion. However, faced with the fundamental problems of grassland agriculture - weed control and often limited fertility - no-tillage agriculture depends heavily on modern herbicides and fertilizers (VandenBygaart 2016). Could soil-paring systems provide inspiration for designing systems in which weeds are controlled by tillage methods less disruptive than deep plowing, allowing reduced herbicide use? These old systems may not yet have outlived their usefulness.

I thank Edmond Dounias (IRD) for his insightful comments on a preliminary version of the manuscript and all my colleagues in CEFE's «Biocultural Interactions and Adaptation " team for the collegial scientific environment from which I benefit. Comments by Gerard Persoon (Leiden University) improved the manuscript. I thank Dr. Lutz Makowsky (University of Applied Sciences Osnabrueck, Osnabrueck, Germany), Prof. Jean de Dieu Nzila (Université Marien Ngouabi, Brazzaville, Congo Republic), and Leonor Rodrigues (Agroscope, Switzerland) for permission to use photographs reproduced in Figures 4, 5, and 6, respectively. My research on human-altered soils has been funded by allocations from the Institut Universitaire de France and by grants from the TOSCA committee (Terre Solide, Océan, Surfaces Continentales, Atmosphère) of the CNES (French National Center for Space Research), from the Institut Ecologie et Environnement (INEE)/CNRS (Projets Exploratoires Pluridisciplinaires TOHMIS), and from the LabEx CeMEB (Centre Méditerranéen Environnement et Biodiversité, Montpellier), an ANR «Investissements d'avenir » program (ANR-10-LABX-04-01).

\section{BIBLIOGRAPHY}

Amare T., Yitaferu B. \& Hurni H. 2013 - Effects of « guie » on soil organic carbon and other soil properties: A traditional soil fertility management practice in the Central Highlands of Ethiopia. Journal of Agricultural Science 5 (7) : 236-244.

Blume H.P. \& Leinweber P. 2004 - Plaggen soils: landscape history, properties, and classification. Journal of Plant Nutrition and Soil Science 167 (3) : 319-327.

Cabot J. 1965 - Le Bassin du Moyen Logone. Paris, ORSTOM, 348 p.

Cairns M.F. (Ed.) 2015 - Shifting Cultivation and Environmental Change: Indigenous People, Agriculture and Forest Conservation. London, Routledge, $1058 \mathrm{p}$.

Christiansen S.1978 - Infield-outfield systems: Characteristics and development in different climatic environments. Geografisk Tidsskrift-Danish Journal of Geography 77 (1) : 1-5. 
Christiansen S. 1996 - Concentrational agriculture: types, functions and derivation. Geografisk Tidsskrift-Danish Journal of Geography 96 : 123-138.

Comptour M., Caillon S., Rodrigues L. \& McKey D. 2018 - Wetland raised-field agriculture and its contribution to sustainability: Ethnoecology of a present-day African system and questions about pre-Columbian systems in the American tropics. Sustainability 10 : 3120. DOI: 10.3390/su10093120

De Keyzer M. 2020 - Sustaining premodern heathlands, 1400-1750. Collective knowledge and peasant communities in the Campine, Belgium. In : Dowling A.P. \& Keyser R. (Ed.), Conservation's Roots: Managing for Sustainability in Preindustrial Europe, 1100-1800. Berghahn Books, New York \& Oxford : 100-126.

Delêtre M. 2004 - Pratiques Culturales, Représentations Culturelles et Gestion de la Diversité Génétique dans les Champs de Manioc du Sud-Est du Gabon. DEA Thesis, Institut National Agronomique ParisGrignon, Paris, France. 2 vols., $42+45$ p.

Denevan W.M. 2001 - Cultivated Landscapes of Native Amazonia and the Andes. Oxford, UK, Oxford University Press, $438 \mathrm{p}$.

Denevan W.M. \& Turner B.L. 1974 - Forms, functions, and associations of raised fields in the Old World tropics. Journal of Tropical Geography 39 : 24-33.

Denham T. 2018 - Tracing early agriculture in the highlands of New Guinea: Plot, mound and ditch. Routledge, London, UK, $330 \mathrm{p}$.

Dove M.R. 1986 - The practical reason of weeds in Indonesia: Peasant versus state views of Imperata and Chromolaena. Human Ecology 14 : 163-190.

Dove M.R. 2004 - Anthropogenic grasslands in Southeast Asia: sociology of knowledge and implications for agroforestry. Agroforestry Systems $61: 423-435$.

Duval M.J., Cochet H. \& Bourliaud J.B. 2007 - L'écobuage andin. Questions sur les origines, l'extension, les modalités et le devenir d'une technique d'ouverture des champs de pomme de terre sur puna humide (Cochabamba, Bolivie). Techniques \& Culture. Revue Semestrielle d'Anthropologie des Techniques 48-49 : 149-188.

Eriksson O., Arnell M. \& Lindholm K.-J. 2021 - Historical ecology of Scandinavian infield systems. Sustainability $13: 817$. https://doi.org/10.3390/su13020817

Fairhead J., Fraser J.A., Amanor K., Solomon D., Lehmann J. \& Leach M. 2017 - Indigenous soil enrichment for food security and climate change in Africa and Asia: A review. In : Sillitoe P. (Ed.), Indigenous Knowledge: Enhancing Its Contribution to Natural Resources Management. CAB International, Wallingford, UK : 99-115.

Fresco L.O. 1986 - Cassava in Shifting Cultivation: A Systems Approach to Agricultural Technology Development in Africa. Wageningen, Netherlands, Royal Tropical Institute, 246 p.

Giani L., Makowsky L. \& Mueller K. 2014 - Plaggic anthrosol: Soil of the Year 2013 in Germany: An overview on its formation, distribution, classification, soil function and threats. Journal of Plant Nutrition and Soil Science 177 (3) : 320-329.

Gimmi U., Poulter B., Wolf A., Portner H., Weber P. \& Bürgi M. 2013 - Soil carbon pools in Swiss forests show legacy effects from historic forest litter raking. Landscape Ecology 28 (5) : 835-846.

Glaser B., Haumaier L., Guggenberger G. \& Zech W. 2001 - The 'Terra Preta' phenomenon: a model for sustainable agriculture in the humid tropics. Naturwissenschaften 88 (1) : 37-41.

Grangeret-Owona I. 1997 - L'Agriculture Bamiléké vue à travers sa gestion de la fertilité agronomique. Thèse doctorale, Faculté Universitaire de Sciences Agronomiques de Gembloux, Belgique, 616 p. 
Grogan K., Birch-Thomsen T. \& Lyimo J. 2013 - Transition of shifting cultivation and its impact on people's livelihoods in the miombo woodlands of northern Zambia and south-western Tanzania. Human Ecology 41 : 77-92.

Guiblais-Starck A., Menbrivès C., Coubray S., Dandurand G., Giosa A., Martin S. \& Petit C. 2020 Première identification archéologique d'un écobuage médiéval : le site de Vaudes « Les Trappes » (Aube). ArcheoSciences 44 (2) : 219-235.

Güldner D., Larsen L. \& Cunfer G. 2021 - Soil fertility transitions in the context of industrialization, 1750-2000. Social Science History 45 (4) : 785-811.

Härdtle W., Assmann T., van Diggelen R. \& von Oheimb G. 2009 - Renaturierung und Management von Heiden. In : Zerbe S. \& Wiegleb G. (Ed.), Renaturierung von Ökosystemen in Mitteleuropa. Spektrum Akademischer Verlag, Heidelberg : 317-347.

Hubbe A., Chertov O., Kalinina O., Nadporozhskaya M., Tolksdorf-Lienemann E. \& Giani L. 2007 Evidence of plaggen soils in European North Russia (Arkhangelsk region). Journal of Plant Nutrition and Soil Science 170 (3) : 329-334.

Itani J. 2002 - Indigenous farming systems in miombo woodlands and surrounding areas in East Africa. Asian and African Area Studies 2 : 88-104.

Koster E.A., Castel I.I. \& Nap R.L. 1993 - Genesis and sedimentary structures of late Holocene aeolian drift sands in northwest Europe. Geological Society, London, Special Publications, 72 (1) : 247-267.

Krings TF. 1991 - Agrarwissen bäuerlicher Gruppen in Mali/Westafrika: standortgerechte Elemente in den Landnutzungssystemen der Senoufo, Bwa, Dogon und Somono. Berlin, Dietrich Reimer Verlag, 301 p.

Mazoyer M. \& Roudart L. 1997 - L'histoire des agricultures du monde. Du Néolithique à la crise contemporaine. Paris, Editions du Seuil, 705 p.

Mboukou-Kimbatsa I. 1997 - Les Macroinvertébrés du sol dans différents systèmes d'agriculture au Congo: Cas particulier de deux systèmes traditionnels (écobuage et brûlis) dans la Vallée du Niari. PhD dissertation, Université de Paris VI Pierre et Marie Curie, 151 p.

McFadgen B.G. 1980 - Maori Plaggen soils in New Zealand, their origin and properties. Journal of the Royal Society of New Zealand 10 (1) : 3-18.

McKey D., Renard D. \& Comptour M. 2017 - Will the real raised-field agriculture please rise? Indigenous knowledge and the resolution of competing visions of one way to farm wetlands. In : Sillitoe P. (Ed.), Indigenous Knowledge. Enhancing Its Contribution to Natural Resources Management. Wallingford, UK. CAB International : 116-129.

Menbrivès C., Petit C., Elliott M., Eddargach W. \& Fechner K. 2019 - Feux agricoles, des techniques méconnues des archéologues. L'apport de l'étude archéopédologique des résidus de combustion de Transinne (Belgique). In : Deák J., Ampe C. \& Mikkelsen J.H. (Ed.), Soils as Records of Past and Present. From Soil Surveys to Archaeological Sites: Research Strategies for Interpreting Soil Characteristics. Proceedings of the Geoarchaeological Meeting. Bruges, Belgium, Stichting Raakvlak : 121-139.

Mertens K., Tolossa A.R., Verdoodt A., Dumon M., Deckers J. \& Van Ranst E. 2015 - Impact of traditional soil burning (guie) on Planosol properties and land-use intensification in southwestern Ethiopia. Soil Use and Management 31 (2) :330-336.

Michellon R., Razakamiaramanana R.R. \& Séguy L. 2001 - Developing sustainable cropping systems with minimal inputs in Madagascar: direct seeding on plant cover with « soil smouldering » (écobuage) techniques. World Congress on Conservation Agriculture Madrid, 1-5 
October, 2001. 6 p. http://open-library.cirad.fr/files/2/460__1004133629.pdf Consulted 6 October 2021.

Miracle M.P. 1967 - Agriculture in the Congo Basin. Tradition and Change in African Rural Economies. Madison, USA, University of Wisconsin Press, 355 p.

Moreau R., Nzila J.D. \& Nyété B. 1998 - La pratique de l'écobuage maala et ses conséquences sur l'état du sol au Congo. 18e Congrès Mondial des Sols, Symposium no 45, 8 p. http://natres.psu.ac.th/link/ soilcongress/bdd/symp45/6997-t.pdf. Consulted 6 October 2021.

Netting R. McC. 1968 - Hill Farmers of Nigeria: Cultural Ecology of the Kofyar of the Jos Plateau. Seattle, USA, University of Washington Press.

Nicolai H. 1963 - Le Kwilu. Étude Géographique d'une Région Congolaise. Bruxelles, Édition CIMUBAC (Centre scientifique et médical de l'Université Libre de Bruxelles en Afrique Centrale), 472 p.

Nzila J.D.D. 2017 - Influences de l'écobuage sur la restauration de la productivité des sols argileux acides de la vallée du Niari (Congo RDC). In : Roose E. (Ed.), Restauration de la Productivité des Sols Tropicaux et Méditerranéens. Marseille, IRD Editions : 141-149.

Olarieta J.R., Besga G. \& Aizpurua A. 2019 - Present soils and past land use: the "bracken economy" in Lea-Artibai County (Basque Country, northern Spain) in the late nineteenth and early twentieth centuries. Historia Agraria 79 : 105-130.

Olarieta J.R., Padrò R., Masip G., Rodríguez-Ochoa R. \& Tello, E. 2011 - ‘Formiguers', a historical system of soil fertilization (and biochar production?). Agriculture, Ecosystems \& Environment 140 (1-2) : 27-33.

Pape J.C. 1970 - Plaggen soils in the Netherlands. Geoderma 4 (3) : 229-255.

Portères R. 1972 - De l'écobuage comme un système mixte de culture et de production. JATBA 19 (6) : 151-207.

Pülschen L. \& Koch W. 1990 - The significance of soil burning ("Guie") in Ethiopia with special regard to its effects on the agrestal weed flora. Journal of Agronomy and Crop Science 164 (4): 254-261.

Rodrigues L., Sprafke T., Moyikola C.B., Barthès B.G., Bertrand I., Comptour M., Rostain S., Yoka J. \& McKey D. 2020 - A Congo Basin ethnographic analogue of pre-Columbian Amazonian raised fields shows the ephemeral legacy of organic matter management. Scientific Reports 10 (1) : 1-12.

Ruthenberg H. 1971 - Farming Systems in the Tropics. Clarendon Press, Oxford, UK, 313 p.

Schmidt M.W., Skjemstad J.O. \& Jäger C. 2002 - Carbon isotope geochemistry and nanomorphology of soil black carbon: Black chernozemic soils in central Europe originate from ancient biomass burning. Global Biogeochemical Cycles 16 (4) : 1123.

Sébillotte M. 1993 - L'agronomie face à la notion de fertilité. Natures-Sciences-Sociétés 1 (2) : 128-141.

Siame J.A. - The Mambwe mound cultivation system. LEISA Magazine, 22 (4) : 14-15.

Sigaut F. 1975 - L'agriculture et le feu. Rôle et place du feu dans les techniques de préparation du champ de l'ancienne agriculture européenne. Paris, Mouton, $320 \mathrm{p}$.

Sigaut F. \& Morlon P. 2010 - Ecobuage. Les Mots de l'Agronomie. https://mots-agronomie.inra.fr/ index.php/\%C3\%89cobuage: Consulted 6 October 2021.

Stromgaard P. 1988 - The grassland mound-system of the Asia Mambwe of Zambia. Tools and Tillage 6 (1) : 33-46. 
Stromgaard P. 1989 - Adaptive sin the breakdown of shifting cultivation: The case of Mambwe, Lamba, and Lala of northern Zambia. Human Ecology 17 (4) : 428-444.

Stromgaard P. 1990 - Effects of mound-cultivation on concentration of nutrients in a Zambian miombo woodland soil. Agriculture, Ecosystems \& Environment 32 (3-4) : 295-313.

Taraken I.T. \& Ratsch R. 2009 - Sweetpotato cultivation on composted mounds in the highlands of Papua New Guinea. In : Kirchhof G. (Ed.), Soil Fertility in Sweetpotato-Based Cropping Systems in the Highlands of Papua New Guinea. Canberra, Australia, ACIAR Technical Reports 71. Australian Centre for International Agricultural Research : 24-32.

Thurston H.D. 1997 - Slash/Mulch Systems. Sustainable Methods for Tropical Agriculture. Boulder, CO, USA, Westview Press, 197 p.

Thurston T.L. 2009 - Farming the margins. On the social causes and consequences of soilmanagement strategies. In : Fisher C.T., Hill J.B. \& Feinman G.M. (Ed.), The Archaeology of Environmental Change. Socionatural Legacies of Degradation and Resilience. Tucson, University of Arizona Press : 106-134.

Uhlig H. 1961 - Old hamlets with infield and outfield systems in Western and Central Europe. Geografiska Annaler 43 (1-2) : 285-312.

Urbanski L., Schad P., Kalbitz K., van Mourik J., Gehrt E. \& Kögel-Knabner I. 2022 - Legacy of plaggen agriculture: High soil organic carbon stocks as result from high carbon input and volume increase. Geoderma 406 : 115513. https://doi.org/10.1016/j.geoderma.2021.115513

VandenBygaart A.J. 2016 - The myth that no-till can mitigate global climate change. Agriculture, Ecosystems \& Environment 216 : 98-99.

Waddell E. 1975 - How the Enga cope with frost: Responses to climatic perturbations in the Central Highlands of New Guinea. Human Ecology 3 (4) : 249-273.

Walters G. 2012 - Customary fire regimes and vegetation structure in Gabon's Bateke Plateaux. Human Ecology 40 (6) : 943-955.

Webb N.R. 1998 - The traditional management of European heathlands. Journal of Applied Ecology 35 (6) : 987-990.

\section{NOTES}

1. To avoid needless repetition, after the first mention of each, the two papers that will be heavily cited here - by Portères (1972) and by Sigaut (1975) - will be cited in the text as «RP » and «FS », respectively.

2. Among the exceptionally favorable soils of mid-latitude grasslands are the black prairie soils known as chernozems, or in the USDA system as mollisols. Long thought to be 'zonal' soils that developed under the natural climatic and geological conditions of the region where they occur, there is mounting evidence that soil-improving effects of anthropogenic fires have contributed to the fertility of mollisols (Schmidt et al. 2002).

3. As forests occcur on a diversity of soils, so do the anthropogenic grasslands derived from them. The native fertility of soils of anthropogenic grasslands is thus variable.

4. The degradation of heathlands by plaggen cultivation produced heterogeneous landscapes (see Figure 5 in Blume \& Leinweber [2004]), including depressions, inland dunes, and large areas of windblown sand, such as the Kootwijkerzand in the Netherlands, the largest area of drift sands in western Europe (Koster et al. 1993). Home to rare plants that depend on these impoverished 
habitats, these plaggen-created landscapes have great patrimonial value. Threatened by eutrophication via atmospheric deposition of nitrate, they are maintained by practices such as abplaggen (removal of sods or vegetation such as moss cover) (Härdtle et al. 2009).

5. In some places, plaggen agriculture may have been less destructive of heathlands. Historical documents show that communities in Belgium imposed strict limits on harvest of sods, and De Keyzer (2020) argues that such regulations often allowed combining plaggen cultivation and sustainable management of heathlands, until 18th-century « reforms » transformed agricultural practices.

6. Systems in which only collected vegetation and litter, but not soil, are transported to stables, enriched with livestock excrement and the mix then spread onto fields, are much more widespread. Some notable examples are from Spain (Olarieta et al. 2019), Switzerland (Gimmi et al. 2013) and Nigeria (Netting 1968).

7. Winter stabling may also have been driven by need to protect cattle from theft, or to increase efficiency of milk and manure production (Eriksson et al. 2021).

8. While slashed material is usually burnt in forest-based systems, "slash-and-mulch» forest systems also exist (Thurston 1997), for example in some areas of western Amazonia where the absence of a marked dry season precludes effective burns (Denevan 2001).

\section{ABSTRACTS}

Compared to traditional (pre-industrial) forest-based agricultural systems, traditional agriculture as practiced in grasslands and heathlands has been neglected, both by agronomists and by ethnoecologists. Examining the diversity of soil-preparation techniques used to cultivate grasslands and heathlands, and the farming systems, both past and present, in which they are enmeshed, opens up unexplored vistas in comparative agriculture. Techniques and systems that have long been studied independently-soil burning in grassland and heathland agriculture throughout the world, historical plaggen cultivation in northern European heathlands, and raised-field agriculture in present-day Africa and New Guinea and pre-Columbian South America -appear on closer inspection to be variants on a common theme. Two syntheses by Roland Portères and François Sigaut in the 1970's, published in French and little cited by authors writing in English, furnish the foundation for a conceptual framework that links these systems and suggests new research questions. This paper updates and extends these syntheses. I show the unity and the diversity of soil-preparation techniques in grassland and heathland agriculture and propose tentative hypotheses about the ecological and social factors explaining the patterns of variation. Finally, I address the pertinence of studying these old systems for agriculture in the 21st century.

Comparée aux systèmes agricoles forestiers traditionnels (préindustriels), l'agriculture traditionnelle pratiquée dans les prairies et les landes a été négligée, tant par les agronomes que par les ethnoécologues. L'examen de la diversité des techniques de préparation du sol utilisées pour cultiver les prairies et les landes, des systèmes agricoles, passés et présents, dans lesquels ces techniques s'inscrivent, ouvre des perspectives inexplorées en agriculture comparée. Des techniques et des systèmes qui ont longtemps été étudiés indépendamment les uns des autres - le brûlage des sols dans l'agriculture des prairies et des landes du monde entier, l'agriculture historique du plaggen dans les landes d'Europe du Nord et l'agriculture sur champs surélevés en 
Afrique et en Nouvelle-Guinée d'aujourd'hui et en Amérique du Sud précolombienne apparaissent, à y regarder de plus près, comme des variantes d'un même thème. Deux synthèses réalisées par Roland Portères et François Sigaut dans les années 1970, publiées en français et peu citées dans la littérature anglophone, fournissent les bases d'un cadre conceptuel qui relie ces systèmes et suggère de nouvelles questions de recherche. Le présent article actualise et approfondit ces synthèses. Nous montrons l'unité et la diversité des techniques de préparation du sol dans l'agriculture des prairies et des landes et nous proposons des hypothèses provisoires sur les facteurs écologiques et sociaux qui expliquent les schémas de variation. Enfin, nous abordons la pertinence de l'étude de ces anciens systèmes pour l'agriculture du XxI ${ }^{\mathrm{e}}$ siècle.

INDEX

Keywords: écobuage, soil-paring systems, soil paring and burning, plaggen agriculture, raisedfield agriculture, compost-mound cultivation, grassland agriculture, heathland

\section{AUTHOR}

\section{DOYLE MCKEY}

Professeur émérite, Université de Montpellier - CEFE, Univ. Montpellier, CNRS, EPHE, IRD, Univ. Paul Valéry Montpellier 3, 1919 route de Mende, 34293 Montpellier cedex 5, France - Téléphone : 0620421344 - doyle.mckey@cefe.cnrs.fr 